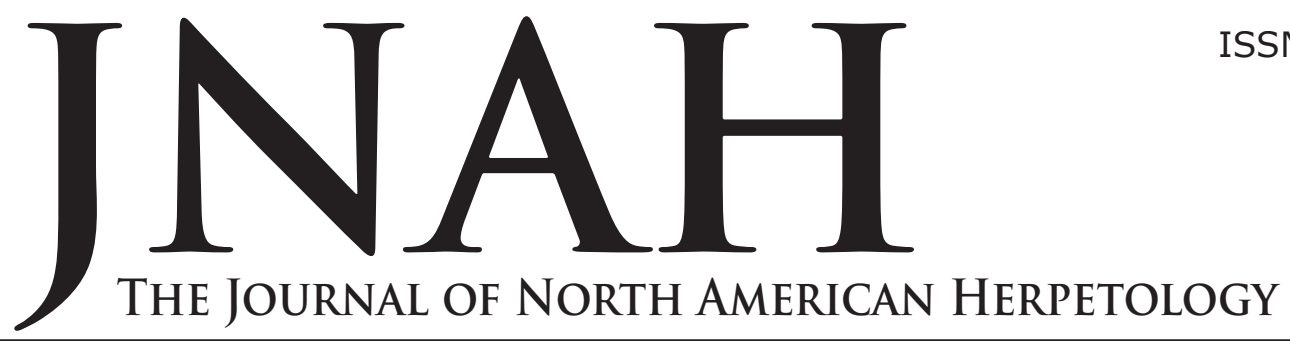

ISSN 2333-0694

\title{
COMPLEX ASSOCIATIONS OF ENVIRONMENTAL FACTORS MAY EXPLAIN BLANCHARD'S CRICKET FROG, ACRIS BLANCHARDI DECLINES AND DRIVE POPULATION RECOVERY
}

\author{
MALCOLM MCCALLUM ${ }^{1,2}$ AND STANLEY E. TRAUTH ${ }^{3}$
}

\author{
${ }^{1}$ P.O. Box 150, Langston, Oklahoma 73050. \\ ${ }^{2}$ Current Address of Corresponding Author: Aquatic Resources Center, School of Agriculture \& Applied \\ Sciences, E.L. Holloway Agriculture Research, Education, \& Extension, Langston University, P.O. Box \\ 1730, Langston, Oklahoma 73050,USA, e-mail: malcolm.mccallum.tamut@gmail.com \\ ${ }^{3}$ P.O. Box 599, Department of Biological Sciences, Arkansas State University (Emeritus),
} State University, Arkansas 72467.

\begin{abstract}
Blanchard's Cricket Frog, Acris blanchardi, is a small hylid frog that was once among the most common amphibians in any part of its range. Today, it remains abundant in much of the southern portion of its range, but is now disappearing elsewhere. Our analysis of habitat characters observed across several states revealed interesting relationships of these factors with the abundance or presence of Blanchard's Cricket Frog. Further, we later established two $1 / 2$ acre ponds based on these relationships that led to immediate colonization of the ponds by cricket frogs followed by explosive production of juveniles less than a year later. Our findings suggest that habitat management for this species should specifically manage the shoreline grade and especially the aquatic floating vegetation to maximize population growth and sustenance.
\end{abstract}

Key Words: amphibians, anurans, habitat, Hylidae, North America, restoration

\section{INTRODUCTION}

Conservation strategies are impaired without a broad understanding of a target's natural history (Bury 2006; McCallum and McCallum 2006; Gilpin 1986). In fact, the progress of an $\mathrm{R}$ or $\mathrm{D}$ extinction vortex pivots on the expression of key life history traits such as reproduction potential and offspring survivorship (Gilpin 1986). An R vortex is one in which a disturbance facilitates reduction in population size, thus increasing vulnerability to additional disturbances. Herein, we hypothesize that floating mats of vegetation may factor into whether populations of Blanchard's Cricket Frog (Acris blanchardi) remain robust, or follow the path of an R extinction vortex to extirpation.

Blanchard's Cricket Frog is a small, short-lived frog (Burkett 1984; McCallum et al. 2011; Letinhen and McDonald. 2011) that was previously designated as a subspecies of the Northern Cricket Frog ( $A$. crepitans) (McCallum and Trauth 2006; Gamble et al. 2008) and currently (but questionably) encompassing the Coastal Cricket Frog ( $A$. blanchardi paludicola [Rose et al. 2006]). It is known for its color polymorphism (Pyburn 1958; 1961; Gray 1972; 1983), zig zag jumping pat- terns (McCallum 2011), and conservation status (Lannoo 1998; 2005).

The color polymorphism refers only to the color or presence of a dorsal stripe running down its back (Gorman 1986; Gray 1984; Milstead et al. 1974), which results from multiple alleles at one locus (Pyburn 1961). However, color diversity in this species is remarkable with spots and splotches of assorted sizes ranging from green to red to brown, and combinations thereof (McCallum Pers. Obs.; Gray and Pantex 1995; Cope 1889). Some of the color variation may be seasonal metachrosis (Cope 1889; Regan 1969; Gray 1972, 1983; Strate 1987). There is evidence that color morph frequency is related to variation in the stream substrate color or due to the presence of vegetation (Nevo 1973a; Pyburn 1961). However, laboratory results using frogs housed in aquaria with American Bullfrogs (Lithobates catesbeianus) or Common Garter Snakes (Thamnophis sirtalis) did not support this hypothesis (Gray 1978; 1984).

When a cricket frog flees from a predator, it frequently jumps 2-3 times at relatively consistent angles away from the predator's attack to optimize distance and angular displacement from the lunging opponent and 
then scurries into a terrestrial or aquatic abode (McCallum 2011). Terrestrially, it will bury itself into a small grassy patch. If it jumps in the water it will often swim back to hide in shoreline vegetation (Gray 1978; McCallum pers. obs.). If it dives, it will often enter a patch of submerged vegetation or floating filamentous algae and remain motionless, floating with the vegetation and the current (McCallum 1999; 2011). Alternatively, it will dive to the bottom, into the mud, remain motionless, and allow the mud to settle on its back. If leaves or other loose materials are on the bottom, it will hide under them. It often avoids moving after being poked or touched while hiding in a patch of vegetation, as if dead (McCallum 1999). It also death-feigns occasionally when held (McCallum 1999). Then, suddenly it jumps away or swims zig-zagged along the bottom and dives again into the benthos or a different aquatic vegetation patch.

These frogs overwinter in cracks and burrows in the soil (Gray 1971; Badje et al. 2016), gravel along streambeds (McCallum and Trauth 2003a) and other terrestrial locations (Irwin et al. 1999; Swanson and Burdick 2010; Kenney et al. 2012; Badje et al. 2016). Outside of hibernation, they tend to occur in terrestrial settings (Smith et al. 2003) within 5-6 cm of a vegetation patch and 10-50 $\mathrm{cm}$ from shore (Burdick and Swanson 2010). However, they sometimes disperse considerable terrestrial distances between wetlands (Gray 1983; McCallum 2003; McCallum et al. 2003; McCallum et al. 2011; Youngquist and Boone 2014). Breeding takes place during MarchOctober, depending on the region, and multiple clutch production is prominent outside of South Dakota (McCallum and Trauth 2004; McCallum et al. 2011). Males call both during day and night (McCallum and McCallum 2018). Young-of-the-year males are capable of reproduction within months of metamorphosis, but females remain immature until the following summer (McCallum et al. 2011). Through most of its range this frog lives one year and the population turns over by October (Bayless 1969; Lehtinen and McDonald 2011; McCallum et al. 2011). However, in more northerly portions of its range (e.g. New York, South Dakota) they may persist a second year (McCallum and Trauth 2004; Lehtinen and MacDonald 2011).

Blanchard's Cricket Frog is declining in the northern parts of its range (Lannoo 1998; Gray and Brown 2005) and it has conservation status in New York (Kenney and Stearns 2015), Michigan (Michigan Natural Features Inventory 2007; Lehtinen 2002), Minnesota (Minnesota Department of Natural Resources 1996), Wisconsin (Wisconsin Department of Natural Resources 2015), South Dakota (Fischer et al. 1999), and appears extirpated from Colorado (Hammerson and Livo 1999); West Virginia (Dickson 2002) and Ontario, Canada (Beauclerc et al. 2010). Causes for the declines may relate to climate change (McCallum 2010; Morgan 2016), contaminants (Reeder et al. 1998; Russel et al. 2002; Reeder et al. 2005; Hayes et al. 2011; Hoskins and Boone 2017), habitat acidification (Lehtinen and Skinner 2006), wetland management (Lannoo 1998; Gordon et al. 2016; Krynak et al. 2016), and other yet unclarified reasons (Dickson 2002; McCallum and Trauth 2003b; Burdick and Swanson 2010). Chytridiomycosis (Steiner and Lehtinen 2008; Zippel and Tabaka 2008), lymphedema (McCallum 2018) and anatomical abnormalities (McCallum and Trauth 2003 b; 2004; Gray 2000a; 2000b) have been reported, sometimes preceding extirpation.

The importance of aquatic vegetation as a habitat feature for this species has been hypothesized (Pyburn

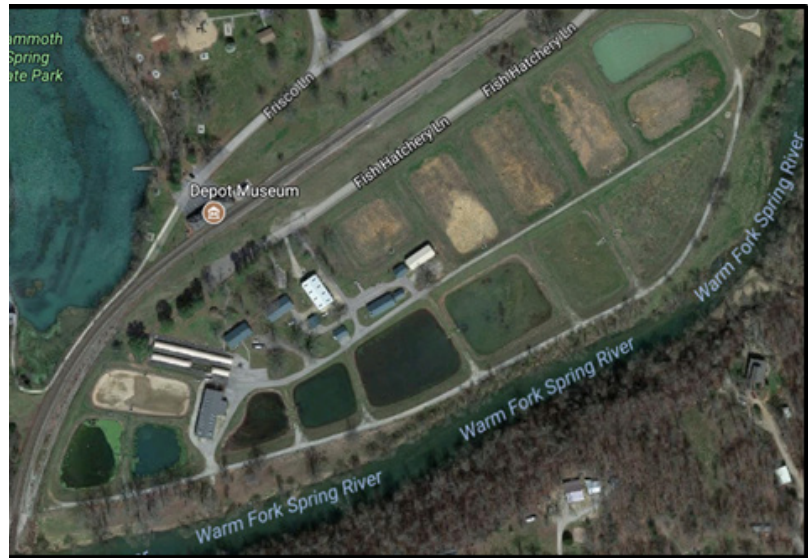

Fig. 1. The Mammoth Spring National Fish Hatchery (Mammoth Spring, Arkansas).

1961; Nevo 1973a; Regan 1973; McCallum 2003; but see Gray 1978; 1984). Herein, we combine numerous field observations with a structured, short-term study to understand the importance of floating vegetation mats and other habitat features to Blanchard's Cricket Frog.

\section{MATERIALS AND METHODS}

The structured study was conducted at the Mammoth Spring National Fish Hatchery (MSNFH) in Mammoth Spring, Arkansas. Additional observations were made in Illinois, Kansas, Louisiana, Michigan, Missouri, Oklahoma, and Texas (Appendix 1). The MSNFH has 15 culture ponds (Fig. 1) used for raising aquatic organisms. The ponds are approximately $10 \mathrm{~m}$ apart. The staff of the MSNFH monitored water quality and maintained similar ranges of standard water quality parameters in all of the ponds. We visited MSNFH during June-August 2000. On each visit, we estimated the percent of the water surface covered by floating mats of Duckweed (Lemna major and Lemna minor) interspersed with filamentous algae (Spirogyra sp. and Clodophora sp.). Then, the perimeter of each pond was surveyed between 1100 and $1300 \mathrm{hrs}$ (this is the peak activity period for Blanchard's Cricket Frog [pers. observ.]). Blanchard's Cricket Frogs were tallied at each pond, noting general habitat parameters (Appendix 1). Minitab 13.3 was used for statistical analysis. Abundance data was tested for normality using the Anderson-Darling normality test, and non-normally distributed data was transformed using the normalize function in Minitab 13.0. Regression analysis used each individual pond and percent vegetation coverage as predictors of frog abundance. An $a=0.05$ was applied for decision theory. Various isolated observations recorded from 1979 to present from numerous Midwestern sites within the frog's range were incorporated into the analysis (Appendix 1). Abundance at each location was qualitatively scored on a scale from $0-5$ for each location $(0=$ absent, 5 = extremely abundant). The abundance scores were statistically tested for associations with shoreline slope ( $<30^{\circ}$ vs $\left.>30^{\circ}\right)$ and presence of numerous general habitat structures. Definitions of vegetation/habitat were necessarily broad to encompass interpretations of notes from the senior author's field journals. These predictors were classified as present $(=1)$ or not present $(=0)$ and subjected to regression analysis to identify relationships among habitat features. Strongly correlated variables were removed from the predictor set. The data were then subjected to best subsets regression to iden- 
Table 1. Estimated floating vegetation coverage versus abundance of Blanchard's Cricket Frog (Acris blanchardi) at Mammoth Spring National Fish Hatchery (Mammoth Spring, Arkansas). D = pond was drained, no water present.

\begin{tabular}{|c|c|c|c|c|c|c|}
\hline \multirow[b]{2}{*}{ Pond \# } & \multicolumn{2}{|c|}{19 June } & \multicolumn{2}{|c|}{19 July } & \multicolumn{2}{|c|}{7 August } \\
\hline & $\%$ veg & \# frogs & $\%$ veg & \# frogs & $\%$ veg & \# frogs \\
\hline 1 & $<5$ & 0 & $<5$ & 0 & $<5$ & 0 \\
\hline 2 & 10 & 19 & $<5$ & 4 & 25 & 89 \\
\hline 3 & 40 & 45 & 40 & 41 & 40 & 31 \\
\hline 4 & $<5$ & 1 & $<5$ & 1 & $<5$ & 0 \\
\hline 5 & $<5$ & 0 & $<5$ & 0 & $<5$ & 0 \\
\hline 6 & $\mathrm{D}$ & 1 & 50 & 101 & 50 & 56 \\
\hline 7 & $\mathrm{D}$ & 0 & $\mathrm{D}$ & 0 & $\mathrm{D}$ & 0 \\
\hline 8 & $<5$ & 7 & 10 & 36 & -- & -- \\
\hline 9 & $\mathrm{D}$ & 0 & 33 & 377 & -- & -- \\
\hline 10 & 25 & 47 & 20 & 20 & -- & -- \\
\hline 11 & 20 & 13 & $<5$ & 3 & -- & -- \\
\hline 12 & 30 & 64 & 30 & 31 & -- & -- \\
\hline 13 & $<5$ & 13 & 30 & 87 & -- & -- \\
\hline 14 & 20 & 43 & $<5$ & 8 & -- & -- \\
\hline 15 & 20 & 41 & $D$ & 0 & & -- \\
\hline
\end{tabular}

tify the best predictors. The regression coefficients of the resulting models with the lowest Mallow's $C_{p}$ Statistic and variance were compared. The five models with the lowest variance and $C_{p}$ were subjected to multiple linear regression. The best regression models were selected by comparing the valence inflation factor (VIF) and predicted residual error sum of squares (PRESS). Durbin-Watson statistic was used to identify potential autocorrelation. Upon analysis of these results, some predictors were combined because of the fine distinctions made between some habitat types.

Upon completing these analyses in July 2016, two $1 / 2$ acre, $2.5 \mathrm{~m}$ deep artificial ponds in the vicinity of Coyle, Oklahoma were flooded with water without aeration or fish, and aquatic Chara sp. and floating algal mats were allowed to grow unrestrained. Frog population sizes were estimated after one and two months. Then, in July 2017 the anuran population was examined to determine if application of key habitat features would benefit Blanchard's Cricket Frog.

\section{RESULTS}

General observations: A small private pond in Collinsville, Illinois had thick mats of duckweed that covered $100 \%$ of the surface during the summer 1979-1984. Blanchard's Cricket Frog was very abundant there. In the summer of 1984, the lake owners introduced carp to control the vegetation. The following year, both the duckweed mats and Blanchard's Cricket Frog were absent from the lake.

Large numbers of Blanchard's Cricket Frogs called from mats of Myriophyllum sp. and Ceratophyllum sp. April-August 2000-2002 at Jane's Creek (Ravenden Springs, Arkansas). Late in the season (June-August) large numbers of new metamorphs used this same habitat. Upon changes in the streambed after repair of the bridge (August 2002), this mat was gone, and the abundance of Blanchard's Cricket Frogs at that location

Table 2. Five best regression models based on outcomes of best subsets regression.

\begin{tabular}{cccc}
\hline $\boldsymbol{r}^{\mathbf{2}}$ & $\mathbf{C}_{\mathbf{p}}$ & $\mathbf{S}$ & Predictors \\
\hline 0.573 & 2.7 & 1.2120 & GBW, SFM, DW, SV, > 30 \\
0.573 & 2.7 & 1.2120 & GB, SFM, DW, SV, > 30 \\
0.593 & 2.4 & 1.1948 & GBW, MFV, SFM, DW, SV, > 30 \\
0.593 & 2.4 & 1.1948 & GB, MFV, SFM, DW, SV, > 30 \\
0.604 & 3.1 & 1.1896 & GBW, MF, MFV, SFM, DW, SV, >30 \\
\hline
\end{tabular}

(2002-2003) dropped from 4.5 metamorphs $/ \mathrm{m}^{2}$ (July 2000-2002) to 2 metamorphs/m² in July 2003.

Structured field study: A total of 1,178 frogs were among all ponds at the MSFH, and 38 (SE $=12.5$ ) frogs/ pond/visit. Both the pond $(T=2.87, P=0.008)$ and percent vegetation coverage $(T=7.60, P<0.001)$ interacted to predict the abundance of Blanchard's Cricket Frogs $\left(r_{2,28}^{2}=0.719, P<0.001\right)$. In the four ponds that had $<5 \%$ vegetation and Blanchard's Cricket Frogs present, the frogs occurred in pockets of emergent vegetation interspersed with duckweed and algal mats (Table $1)$.

Analysis of Field Notes: The results from analysis of field notes produced five models with VIF $<3.1$ and S $=1.1896-1.2120$ and $r^{2}=0.573-0.504$ (Table 2). Floating mats of sphagnum, duckweed/algae, and submerged vegetation along the water surface were positive predictors in $71.0 \%$ of the 31 models produced from best subsets regression. A shoreline with a slope $>30^{\circ}$ was a negative predictor of cricket frog abundance in $83.9 \%$ of the 31 models produced. These factors appeared in all of the five best models predicting abundance of Blanchard's Cricket Frog. The models indicated that gravel shorelines with light vegetation were a positive predictor in $58.1 \%$ of study sites and without vegetation in $51.6 \%$ of habitats. Three of the five best models included unvegetated gravel shorelines, and two included vegetated gravel shorelines. None of the five best models included both types of gravel shorelines. Multiple linear regression analysis of each of the five best models revealed lack of fit for the models with greater than five predictors (Appendix 2) and a minimal influence of light vegetation on gravel banks.

Reanalysis of these data after combining the various vegetation mats (Sphagnum [SFM] + duckweed [DM] + thick submerged vegetation like Ceratophyllum or Myrio-

Table 3. Five best regression models based on outcomes of best subsets regression after combining some predictors. ( $G=$ gravel banks, FM = floating vegetation mats, $\mathrm{SB}=$ sand bottom, CTG = cattails or tall grasses, $30^{\circ}=$ slope of the stream or pond bank).

\begin{tabular}{cccc}
\hline $\boldsymbol{r} 2$ & Cp & s & Predictors \\
\hline 0.603 & 1.7 & 1.1478 & G, FM, > 30 \\
0.619 & 1.6 & 1.1349 & G, SB, FM, > 30 \\
0.617 & 1.8 & 1.1368 & G, CTG, FM, > 30 \\
0.634 & 1.6 & 1.1225 & G, CTG, SB, FM, > 30 \\
0.630 & 2.1 & 1.1287 & G, CTG, SB, FM, <30 \\
\hline
\end{tabular}



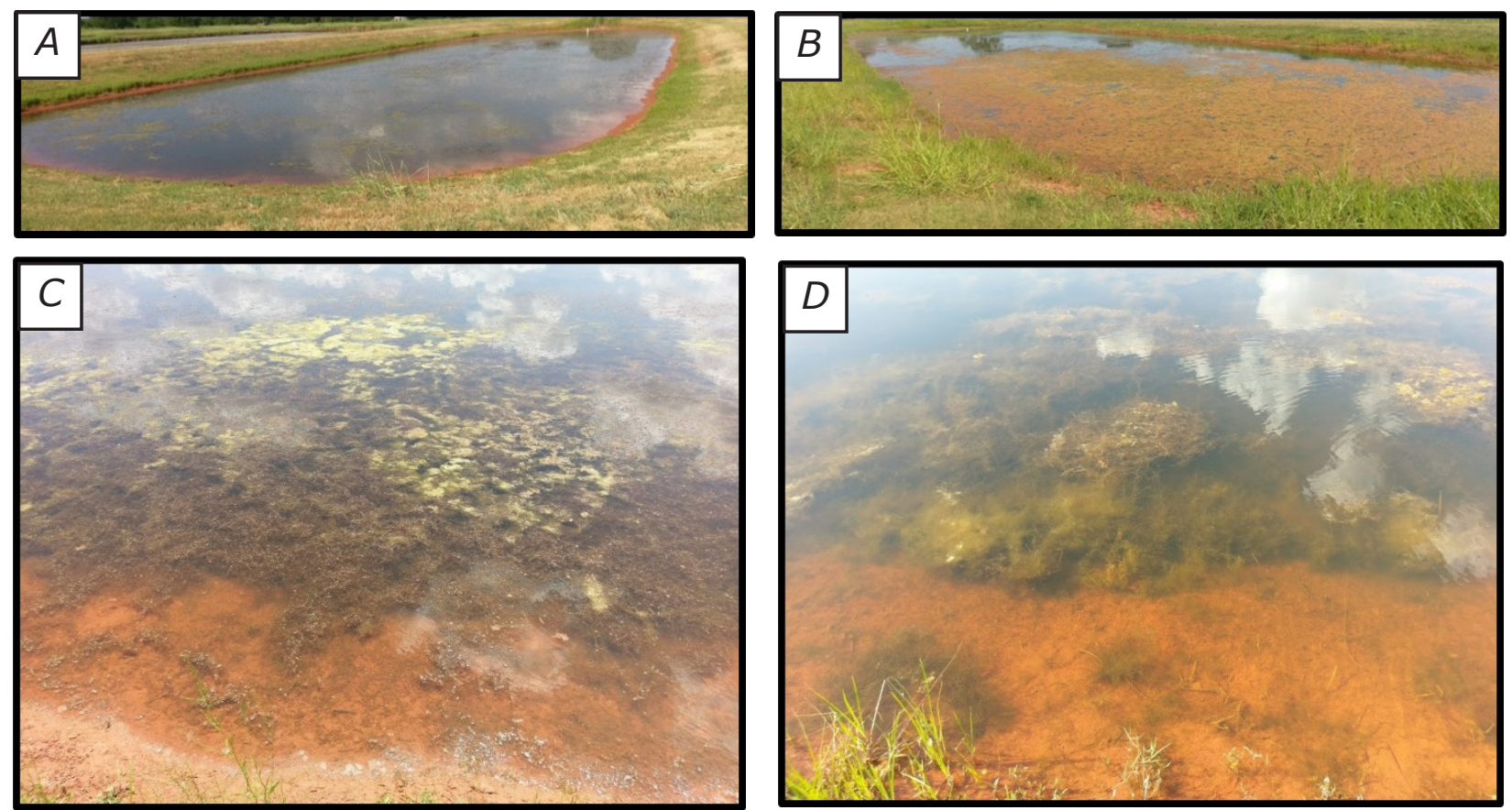

Fig. 2. Two half-acre, fishless ponds with aquatic vegetation. Although the shoreline appears sloped in the photo, the angle at the water's edge is very low grade. Grass was mowed along the edges to maintain short vegetation. Ponds are labeled A and B for reference in Fig. 3 and 4. C) Chara sp. interspersed with Cladaphora sp. in Pond A. D) Filamentous algae dominating aquatic vegetation in Pond $B$.

phyllum $[\mathrm{SV}]=\mathrm{FM}$ ) and the gravel bank types revealed that that there was still high correlation among habitats with RGV (bedrock with some gravel and taller vegetation) and other predictors. So, it was removed from the analysis. Best subsets regression identified the five best models among 23 combinations of possible predictors for frog abundance (Table 3) with $r^{2}=0.603-0.634$. The five best models had $C_{p}=1.6-2.1$ and variances of $1.1225-$ 1.1478. Thick floating mats of vegetation (FM) were predictors of frog presence in $96.0 \%$ of the models, and all five of the best relationships identified. A slope greater than $30^{\circ}$ was an important predictor of frog absence in $87.0 \%$ of the 23 models generated and four of the five best models identified. Gravel banks predicted frog presence in $78.2 \%$ of the generated models and all of the five best models. Cattails and/or thick tall grasses on the shoreline predicted absence of frogs in $78.2 \%$ of the generated models, but were used in three of the best five models. No autocorrelation was identified; however, lack of fit was detected in all of the new models except for

Abundance $=1.50+1.12 \mathrm{G}-0.514 \mathrm{CTG}+1.93 \mathrm{FM}+$ -1.02 (slope $>30^{\circ}$ ) (Appendix 3 ).

where $\mathrm{G}=$ gravel, $\mathrm{CTG}=$ thick cattails or tall grasses in the water or along the shoreline, and FM = floating vegetation mats.

By May 2017, the artificial ponds in Oklahoma had $25 \%$ surface coverage by algal mats and aquatic vegetation was evident. The conditions of the two ponds by July 2017 are shown in Figure 2. Blanchard's Cricket Frog did not immediately colonize the two newly flooded artificial ponds. The nearest populations of this species occurred in a stream about 305 m. During Spring 2017, they began colonizing the ponds with calling choruses at each pond easily exceeding 50 frogs. By July 2017, the population had exploded as seen in provided video (Fig. 3 ). Each splash in the water is an individual frog entering it from the shoreline. Also, of note is the immense number of juveniles perching upon the floating vegetation across the surface of each pond (Fig. 3). Finally, this population growth was accomplished despite a strong American Bullfrog (Lithobates catesbeianus) population (199 and 211 bullfrogs in each pond as of May 2017).

\section{DISCUSSION}

Previous studies have investigated or commented on the habitat needs of this very adaptable species that can persist in many situations (Martinez-Ortiz 2004). Most accounts suggest these frogs are largely generalized shoreline residents (Conant and Collins 1998). However, we proffer that floating mats of vegetation such as Sphagnum sp., Myriophyllum sp., Ceratophyllum sp., duckweed (Lemna sp.), Chara sp., and filamentous algae (Spirogyra sp., Cladophora sp.) can be important habitat components for Blanchard's Cricket Frog. At MSNFH, these frogs migrated from one culture pond to another and congregated in areas with this habitat feature, especially during breeding season and during emergence of metamorphs. Here and at many other locations, Duckweed and filamentous algae constitute the primary structural components of these mats. However, the other aforementioned floating plant species appear equally useful.

The slope of the shoreline is important as well. Lowslopes are conducive to breeding choruses and foraging habitat. Habitats along rivers and streams that are steep tend not to serve as habitat. Muddy banks in and of themselves do not appear to be a strong predictor of cricket frog occurrence; however, many regions where this species exists are dominated by soil banks and the frogs persist there. Gravel banks tend to be occupied by 

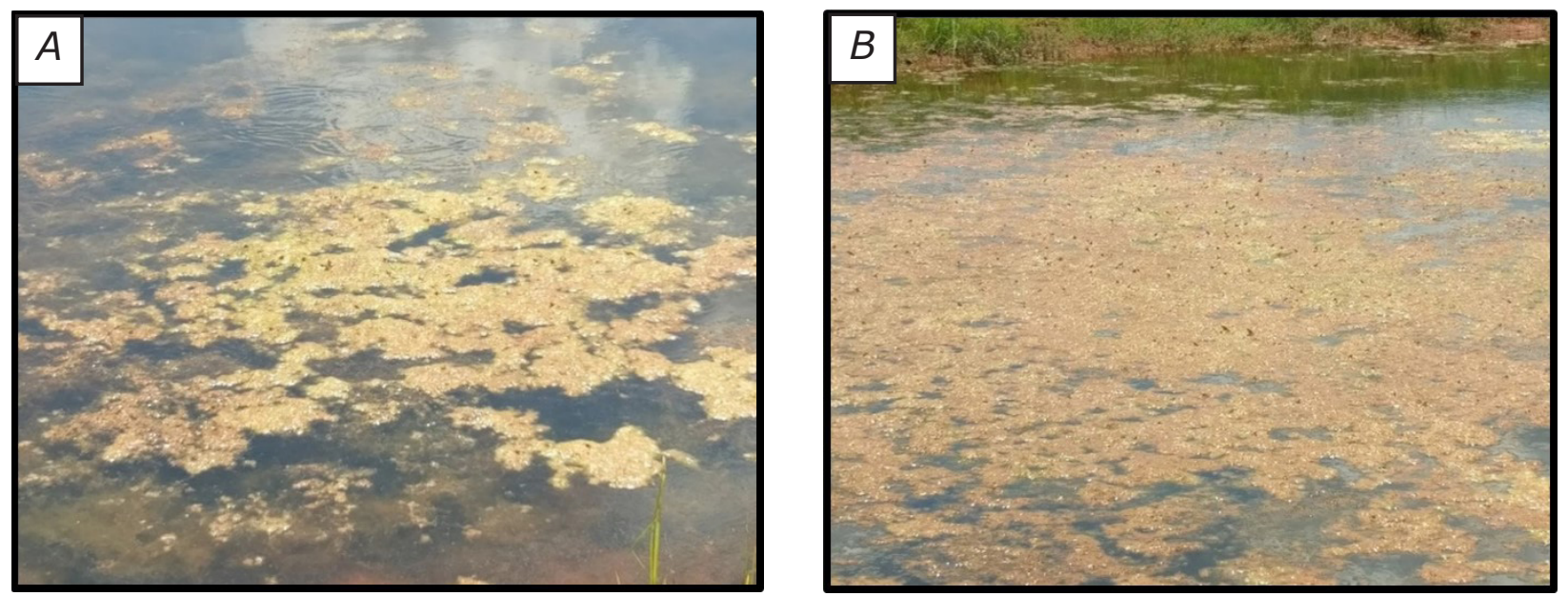

Fig. 3. Abundance of Blanchard's Cricket Frogs (Acris blanchardi) in pond microhabitats. A) At least 28 frogs perched on small, thin algal mat ( $3 \mathrm{~m}$ long) with submersed Chara sp. in Pond A. B) Hundreds of Blanchard's Cricket Frogs and dozens of juvenile American Bullfrogs (Lithobates catesbieanus) utilizing floating algal mats in Pond B. C) Video of Blanchard's Cricket Frogs actively foraging on floating vegetation (click to view)

these frogs. In general, if a habitat has gravel banks, floating mats of vegetation, and a low sloped shore, a high probability exists that the site will or can harbor Blanchard's Cricket Frogs. However, if it has a steep bank or thick cattails or tall grasses along the shore, it is unlikely to be present.

Contrary to this study, mud banks were previously identified as primary habitat for this species in West-central Missouri, although proximity to shelter and water played a role (Smith et al. 2003). This region of Missouri is dominated by sandy and muddy creeks and ponds. Some creeks have gravel substrates, but even those creeks commonly have muddy banks. In South Dakota, Blanchard's Cricket Frog is found in mud and vegetated habitats close to stream edges (Burdick and Swanson 2010). It is possible that differences between our results and laboratory observations reflect the familiarity of the individuals tested and the availability of habitat in West-central Missouri. A frog that spent its entire life on a muddy bank should be expected to associate with muddy substrates over other types simply because of its familiarity with them (Aitken 1972; Sheldon 1969; Hughes 1997). Availability of habitat may also explain the field observations associating Blanchard's Cricket Frog with mud banks in Missouri (Smith et al. 2003), South Dakota (Burdick and Swanson 2010), and Illinois (Gray 1984). Most streams and ponds in these specific areas have mud banks. Our study spans these regions, thus providing a wider diversity of habitat types for prediction of abundance and occurrence. This suggests gravel banks as a better predictor of cricket frog occurrence and abundance.

During the summer, cricket frogs will follow floating vegetation mats into open water. At the sphagnum bog in Michigan, we observed Blanchard's Cricket Frog on sphagnum above the deepest portions of the lake. At Arkansas Post, we observed Blanchard's Cricket Frog on floating vegetation $>50 \mathrm{~m}$ from shore. Anecdotal observations at the quaking sphagnum bog in Michigan were at least this distance from the shoreline. Regan (1973) provided photographs of habitat in Kansas which resembled the habitats we investigated in this study, we observed at previous locations, and these appear to be present at Glenmere, New York. Removal of thick mats of float- ing vegetation tends to be the trend in most managed systems, for the convenience of anglers. The last foothold for Blanchard's Cricket Frog in New York is a heavily vegetated lake (Glenmere Conservation Coalition, Pers. Comm.). Photographs posted on their photo gallery site (linked here and last accessed on 4 June 2021) showed ponds with floating sphagnum mats.

In much of the Midwest, where these frogs are declining, the use of herbicides negatively impacts their persistence. Much attention has targeted direct impacts of these agrichemicals on the reproductive biology and stress response of Blanchard's Cricket Frog (Reeder et al. $1998 ;$ 2005). However, this may be of secondary importance or only a partial explanation of declines. Vegetation mats can serve as important nurseries as evidenced by the high numbers of metamorphs observed in association with them (McCallum et al. 2011). Regan (1973) also anecdotally mentioned the use of floating vegetation by Blanchard's Cricket Frog and hypothesized on its possible importance for tadpoles. Further, floating mats of vegetation allow these frogs to move across ponds and lakes, far from terrestrial and semi-aquatic predators.

The zigzagged escape behavior (McCallum 2011) may be especially effective in aquatic settings when vegetation mats are present. The mats provide refuge, and a multi-colored frog hiding in vegetated mats of duckweed is fairly cryptic. Otherwise, Blanchard's Cricket Frog should be easy for wading birds and other predators to capture when the complex structure of these mats is not available. Likewise, large frogs like American Bullfrogs may have more difficulty catching a rapidly moving cricket frog while on a vegetation mat compared to in shallow water or on the shore. Cricket frogs are light and appear to jump as effectively on duckweed mats as on land. However, larger frogs and other predators sink into this material and are at a fairly obvious mobility disadvantage. In fact, laboratory findings suggest that if Blanchard's Cricket Frog is confined in a small space with a predator, it becomes easy prey for predators like bullfrogs (Gray 1978). The evolutionary drive for their jumping behavior depends on the ability to displace and distance itself from an on-looking predator (McCallum 2011). Availability of refuges should facilitate its effectiveness. Vegetation mats may provide unlimited refuge 
from predators; an advantage to otherwise conspicuous calling males. Small metamorphs occupying mats are very difficult to find once they bury into the thick floating vegetation (pers. obs.); an especially beneficial antipredator behavior from predators that include conspecifics (McCallum and Trauth 2001), at this early age.

Many of the chemicals implicated in the declines of Blanchard's Cricket Frog are herbicides that negatively impact duckweed (Hughes et al. 1988; Hoberg 1993; Solomon et al. 1996; Teodorovic et al. 2012), algae (Fairchild et al. 1998), Ceratophyllum sp. (Solomon et al. 1996; Huiyun et al. 2009; Fairchild et al. 1998), and other aquatic plants (Teodorovic et al. 2012; but see Kemp et al. 1985; Jones and Winchell 1984). Therefore, it is quite possible that these herbicides are even more detrimental for cricket frogs when they kill off aquatic vegetation than when they elicit endocrine disruption. Loss of this important habitat component could rapidly lead to extirpation from a locality, especially in light of its short life span (McCallum et al. 2011) simply by exposing them to many small-scale hurdles to survivorship instead of a major catastrophe. In this scenario, these chemicals first induce physiological stress (Jones et al. 2010), potentially reducing their available energy for predator deterrence and resources for stressor neutralization (McCallum and Trauth 2007). Second, they suppress the development of thick floating mats of vegetation. Third, herbicides disrupt reproduction. We suspect that these three strikes could interact in ways that are more disruptive than any single one unto itself. This may explain why clear identification of a single over-riding factor stimulating declines has been so elusive. It might be prudent for researchers on amphibian declines to cast wide nets to find answers rather than fix their targets on specific individual elements. Multiple stressors are almost certainly a more common problem that has thus far been addressed (see Linder et al. 2003). Multiple stressor effects can have additive, facilitative, multiplicative, or even antagonistic interactions with each other (Crain et al. 2008; Folt et al. 1999; Vinebrooke 2004; Newman 2009). So, many small stressors may elicit declines more effectively and more elusively than any single major threat, leading to extirpation or extinction.

Our application of these observations in aquaculture ponds suggests population enrichment is easily accomplished with simple modifications to pond habitat. Management and restoration of this species must include promotion of aquatic vegetation, especially species such as duckweed, Ceratophyllum sp. and Spirogyra sp. that form dense floating mats. Plant species like Myriophyllum sp. that extend up from the substrate and then float along the surface also provide similar habitat. The slope of pond and stream shorelines is also critical. Finally, exclusion of cattails and similar plants from shorelines may assist in the recovery of this frog. Therefore, pond owners should manage small areas of their ponds with these observations in mind.

This study did not involve handling or manipulation of animals, and was conducted under the guidelines of the Animal Welfare Act.

\section{REFERENCES}

Aitken P.P. 1972. Aversive stimulation and rats' preference for familiarity. Psychonomic Science 28:281282.

Badje A.F., T.J. Brandt, T.L. Bergeson, R.A. Paloske, J.M. Kapfer, G.W. Schuurman. 2016. Blanchard's crick- et frog (Acris blanchardi) overwintering ecology in southwestern Wisconsin. Herpetological Conservation and Biology 11:101-111.

Bayless, L. 1969. Post-metamorphic growth in Acris crepitans. American Midland Naturalist 81:590-592.

Beauclerc, K.B., B. Johnson, B.N. White. 2010. Distinctiveness of declining northern populations of Blanchard's Cricket Frog (Acris blanchardi) justifies recovery efforts. Canadian Journal of Zoology 88:553-566.

Burdick, S.L., D.L. Swanson. 2010. Status, distribution, and microhabitats of Blanchard's Cricket Frog, Acris crepitans, in South Dakota. Herpetological Conservation and Biology 5:9-16.

Burkett, R. 1984. An ecological study of the cricket frog, Acris crepitans. Pp. 89-102 In: Seigel, R., L. Hunt, J. Knight, L. Malaret, N. Zuschlag (eds.) Vertebrate Ecology and Systematics - A tribute to Henry S. Fitch. University of Kansas Press. Lawrence, Kansas, U.S.A.

Bury, R.B. 2006. Natural history, field ecology, conservation biology and wildlife management: Time to connect the dots. Herpetological Conservation and Biology 1:56-61.

Conant, R., J.T. Collins. 1998. A Field Guide to Reptiles and Amphibians: Eastern and Central North America. Houghton Mifflin Harcourt. Boston, Massachusetts, U.S.A.

Crain, C.M., K. Kroeker, B.S. Halpern. 2008. Interactive and cumulative effects of multiple human stressors in marine systems. Ecology Letters 11:1304-1315.

Cope, E.D. 1889. The Batrachia of North America (Vol. 34). US Government Printing Office.

Dickson, N.J. 2002. The natural history and possible extirpation of Blanchard's Cricket Frog, Acris crepitans blanchardi, in West Virginia. Unpublished Dissertation. Marshall University. Huntington, West Virginia, U.S.A.

Fairchild, J.F., D.S. Ruessler, A.R. Carlson. 1998. Comparative sensitivity of five species of macrophytes and six species of algae to atrazine, metribuzin alachlor, and metolachlor. Environmental Toxicology and Chemistry 9:1830-1834.

Fischer, T.D., D.C. Backlund, K.F. Higgins, D.E. Naugle. 1999. A field guide to South Dakota amphibians. SDAES Bulletin 733. South Dakota State University. Brookings, South Dakota, U.S.A.

Folt, C.L., C.Y. Chen, M.V. Moore, J. Burnaford. 1999. Synergism and antagonism among multiple stressors. Limnology and Oceanography 44:864-877.

Gamble, T., P.B. Berendzzen, H.B. Shaffer, D.E. Starkey, A.M. Simon. 2008. Species limits and phylogeography of North American cricket frogs (Acris: Hylidae). Molecular Phylogenetics and Evolution 48:112-125.

Gilpin, M.E. 1986. Minimum viable populations: Processes of Species Extinction. In Soule ME, Conservation Biology: The Science of Scarcity and Diversity. Sinauer and Associates. Sutherland, Massachusetts, U.S.A.

Gordon, A.M., M.B. Youngquist, M.D. Boone. 2016. The effects of pond drying and predation on Blanchard's Cricket Frogs (Acris blanchardi). Copeia 104:482486.

Gorman, W.L., M.S. Gaines. 1987. Patterns of genetic variation in the cricket frog, Acris crepitans, in Kansas. Copeia 1987:352-360. 
Gorman, W.L. 1986. Patterns of color polymorphism in the cricket frog, Acris crepitans, in Kansas. Copeia 1986: 995-999.

Gray, R.H. 1971. Fall activity and overwintering of the cricket frog (Acris crepitans) in central Illinois. Copeia 1971:748-750.

Gray, R.H. 1972. Metachrosis of the vertebral stripe in the cricket frog, Acris crepitans. American Midland Naturalist 1972:549-551.

Gray, R.H. 1977. Lack of physiological differentiation in three color morphs of the cricket frog (Acris crepitans) in Illinois. Transactions of the Illinois Academy of Science 70:73-79.

Gray, R.H. 1978. Nondifferential predation susceptibility and behavioral selection in three color morphs of Illinois cricket frogs, Acris crepitans. Transactions of the Illinois Academy of Science 71:356-360.

Gray, R.H. 1983. Seasonal, annual and geographic variation in color morph frequencies of the Cricket Frog, Acris crepitans, in Illinois. Copeia 1983:300-311.

Gray, R.H. 1984. Effective breeding size and the adaptive significance of color polymorphism in the cricket frog (Acris crepitans) in Illinois, USA. Amphibia-Reptilia 5:101-107.

Gray, R.H. 2000 a. Morphological abnormalities in Illinois Cricket Frogs, Acris crepitans, 1968 - 71. Journal of the Iowa Academy of Science 107:92-95.

Gray, R.H. 2000 b. Historical occurrence of malformations in the cricket frog, Acris crepitans, in Illinois. Transactions of the Illinois Academy of Science 93:279-284.

Gray, R.H., L.E. Brown. 2005. Decline of northern cricket frogs (Acris crepitans). Pp. 47-54 In: Lannoo MA. Amphibian Declines: The Conservation Status of United States Species. University of California Press. Berkeley, California, U.S.A.

Gray, R.H., B. Pantex. 1995. An unusual color pattern variant in cricket frogs (Acris crepitans) from Southern Illinois. Transactions of the Illinois Academy of Science 83:137-138.

Hammerson, G.A., J.L. Livo. 1999. Conservation status of the Northern Cricket Frog (Acris crepitans) in Colorado and adjacent areas at the Northwestern extent of its range. Herpetological Review 30:78-79.

Hayes, T.B., L.L. Anderson, V.R. Beasley, S.R. de Solla, T. Iguchi, H. Ingraham, P. Kestemont, J. Kniewald, Z. Kniewald, V.S. Langlois. 2011. Demasculinization and feminization of male gonads by atrazine: Consistent effects across vertebrate classes. The Journal of Steroid Biochemistry and Molecular Biology 127:64-73.

Hoskins, T.D., M.D. Boone. 2017. Variation in Malathion sensitivity among populations of Blanchard's cricket frogs (Acris blanchardi) and implications for risk assessment. Environmental Toxicology and Chemistry (In Press).

Hughes, R.N. 1997. Intrinsic exploration in animals: motives an measurement. Behavioural Processes 41:213-226.

Huiyun, P., L.I. Xiaolu, X.U. Xiaohua, G.A.O. Shixiang. 2009. Phytotoxicity of four herbicides on CeratophylIum demersum, Vallisneria natans, and Elodea nuttalli. Journal of Environmental Sciences 2:307-312.

Irwin, J.T., J.P. Costanzo, R.E. Lee, Jr. 1999. Terrestrial hibernation in the northern cricket frog, Acris crepitans. Canadian Journal of Zoology 77:1240-1246.

Jones, T.W., L. Winchell. 1984. Uptake and photosynthetic inhibition by Atrazine and its degradation products on four species of submerged vascular plants. Journal of Environmental Quality 13:243-247.

Kemp, W.M., W.R. Boynton, J.J. Cunningham, J.C. Stevenson, T.W. Jones, J.C. Means. 1985. Effects of atrazine and linuron on photosynthesis and growth of the macrophytes, Potamogeton perfoliatus $L$. and Myriophyllum spicatum $L$. in an estuarine environment. Marine Environmental Research 16:255-280.

Kenney, G., C. Stearns. 2015. Recovery plan for New York State populations of the Northern Cricket Frog (Acris crepitans). New York State Department of Conservation. Albany, New York, U.S.A.

Kenney, G., K. McKean, J. Martin, C. Stearns. 2012. Identification of terrestrial wintering habitat of Acris crepitans (Northern Cricket Frog). Northeastern Naturalist 19:698-700.

Krynak, K.L., D.J. Burke, M.F. Benard. 2016. Landscape and water characteristics correlate with immune defense traits across Blanchard's cricket frog (Acris blanchardi) populations. Biological Conservation 193:153-167.

Lannoo, M.J. 1998. Amphibian conservation and wetland management in the Upper Midwest: A catch-22 for the cricket frog? Pp. 330-339 In: Lannoo, M.J. (ed.) Status and Conservation of Midwestern Amphibians. University of Iowa Press. Iowa City, Iowa, U.S.A.

Lannoo, M.J. 2005. Amphibian declines: The conservation status of United States species. University of California Press. Berkeley, California, U.S.A.

Lehtinen, R.M. 2002. A historical study of the distribution of Blanchard's Cricket Frog (Acris crepitans blanchardi) in southeastern Michigan. Herpetological Review 33:194-197.

Lehtinen, R.M., M.C. MacDonald. 2011. Live fast, die young? A six-year field study of longevity and survivorship in Blanchard's Cricket Frog (Acris crepitans blanchardi). Herpetological Review 42:504-507.

Lehtinen, R.M., A.A. Skinner. 2006. The enigmatic decline of Blanchard's cricket frog (Acris crepitans blanchardi): A test of the habitat acidification hypothesis. Copeia 2006:159-167.

Linder, G.; S. Krest, D. Sparling, and E. Little (editors). 2003. Multiple stressor effects in relation to declining amphibian populations. ASTM International, West Conshohocken, PA, USA.

Martinez-Ortiz, M. 2004. Predicting habitat suitability and occurrence for Blanchard's Cricket Frogs (Acris crepitans blanchardi) in Northwest Ohio. Unpublished Master Thesis. Bowling Green State University. Bowling Green, Ohio, U.S.A.

McCallum, M.L. 1999. Acris crepitans (Northern Cricket Frog) Death feigning. Herpetological Review 30: 129.

McCallum, M.L. 2003. Reproductive ecology and taxonomic status of Acris crepitans blanchardi, with additional investigations on the Hamilton and Zuk Hypothesis. Unpublished Dissertation. Arkansas State University. Jonesboro, Arkansas, U.S.A.

McCallum, M.L. 2010. Future climate change spells catastrophe for Blanchard's Cricket Frog, Acris blanchardi (Amphibia: Anura: Hylidae). Acta Herpetologica 5:119-130.

McCallum, M.L. 2011. Orientation and directional escape by Blanchard's Cricket Frog, Acris blanchardi (Amphibia: Anura: Hylidae), in response to a human predator. Acta Herpetologica 6:161-168.

McCallum, M.L. 2018. Occurrence of lymphedema in wild-caught anurans. bioRXiv 336131. 
McCallum, M.L., J.L. McCallum. 2006. Publication trends of natural history and field studies in herpetology. Herpetological Conservation and Biology 1:63-68.

McCallum, M.L., J.L., McCallum. 2018. Diurnal chorusing in nine species of North American frogs. bioRXiv 336149.

McCallum, M.L., S.E. Trauth. 2001. Acris crepitans (Northern Cricket Frog). Attempted cannibalism. Herpetological Review 32:99-100.

McCallum, M.L., S.E. Trauth. 2003 a. Acris crepitans (Northern Cricket Frog). Communal hibernaculum. Herpetological Review 34:228.

McCallum, M.L., S.E. Trauth. 2003 b. A forty-three year museum study of northern cricket frog (Acris crepitans) abnormalities in Arkansas: Upward trends and distributions. Journal of Wildlife Diseases 39:522528.

McCallum, M.L., S.E. Trauth. 2004. Blanchard's Cricket Frog in Nebraska and South Dakota. Prairie Naturalist 36:129-135.

McCallum, M.L., S.E. Trauth. 2006. An evaluation of the subspecies Acris crepitans blanchardi (Anura, Hylidae). Zootaxa 1104:1-21.

McCallum, M.L., S.E. Trauth. 2007. Physiological tradeoffs between immunity and reproduction in the northern cricket frog (Acris crepitans). Herpetologica 63:1057-1062.

McCallum, M.L., C. Brooks, R. Mason, S.E. Trauth. 2011. Growth, reproduction, and life span in Blanchard's Cricket Frog (Acris blanchardi) with notes on the growth of the Northern Cricket Frog (Acris crepitans). Herpetology Notes 4:25-30.

McCallum, M.L., S.E. Trauth, R.G. Neal, V. Hoffman. 2003. A herpetofaunal inventory of Arkansas Post National Monument, Arkansas County, Arkansas. Journal of the Arkansas Academy of Science 57:122-130.

Michigan Natural Features Inventory (2007) Rare species explorer (Web Application). Available online at http://mnfi.anr.msu.edu/explorer [accessed April 11, 2017].

Milstead, W.W., A.S. Rand, M.M. Stewart. 1974. Polymorphism in cricket frogs: An hypothesis. Evolution 28:489-491.

Minnesota Department of Natural Resources. 1996. Acris blanchardi. Rare species guide. Available online at http://www.dnr.state.mn.us/rsg/profile.html?action=elementDetail\&selectedElement $=$ AAABC01040 [accessed 11 April 2017].

Morgan, C.L. 2016. Experimental treatment and thermally-mediated variation of Batrachochytrium dendrobatidis infection in a north central Texas Population of Acris blanchardi. Unpublished Master Thesis. Tarelton State University.

Nevo, E. 1973 a. Adaptive color polymorphism in cricket frogs. Evolution 1973:353-367.

Nevo, E. 1973 b. Adaptive variation in size of cricket frogs. Ecology, 54(6), 1271-1281.

Newman, M.C. 2009. Fundamentals of Ecotoxicology. CRC Press. Baca Raton, Florida, U.S.A.

Pyburn, W.F. 1958. Size and movements of a local population of cricket frogs (Acris crepitans). Texas Journal of Science 10:325-342.

Pyburn, W.F. 1961. The inheritance and distribution of vertebral stripe color in the cricket frog, Pp. 235261 In: Blair, W.F. (ed.) Vertebrate Speciation. University of Texas Press. Austin, Texas, U.S.A.

Reeder, A.L., G.L. Foley, D.K. Nichols, L.G. Hansen, B. Wikoff, S. Faeh, J. Eisold, M.B. Wheeler, R. Warner,
J.E. Murphy, V.R. Beasley. 1998. Forms and prevalence of intersexuality and effects of environmental contaminants on sexuality in cricket frogs (Acris crepitans). Environmental Health Perspectives 106:261-266.

Reeder, A.L., M.O. Ruiz, A. Pessier, L.E. Brown, R.E. Warner, V.R. Beasley. 2005. Intersexuality and the cricket frog decline: historic and geographic trends. Environmental Health Perspectives 113:261-265.

Regan, G. T. 1969. Color dimorphism in the larval cricket frog Acris crepitans. Proceedings of the Nebraska Academy of Sciences and Affiliated Societies. 79 (1969): 10-11.

Regan, G.T. 1973. Natural and man-made conditions determining the range of Acris crepitans in the Missouri River Basin. Unpublished Dissertation. University of Kansas, Lawrence, Kansas, U.S.A.

Rose, F.L., T.R. Simpson, M.R.J. Forstner, D.J. McHenry, J. Williams. 2006. Taxonomic status of Acris gryllus paludicola: In search of the pink frog. Journal of Herpetology 40:428-434.

Russell, R.W., G.J. Lipps, Jr., S.J. Hecnar, G.D. Haffner. 2002. Persistent organic pollutants in Blanchard's Cricket Frog (Acris crepitans blanchardi) from Ohio. The Ohio Journal of Science 102:119-122.

Sheldon, A.B. 1969. Preference for familiar versus novel stimulus as a function of the familiarity of the environment. Physiological Psychology 67:516-521.

Smith, G.R., A. Todd, J.E. Rettig, E. Nelson. 2003. Microhabitat selection by northern cricket frogs (Acris crepitans) along a west-central Missouri creek: Field and experimental observations. Journal of Herpetology 37:383-385.

Steiner, S., R. Lehtinen. 2008. Occurrence of the amphibian pathogen Batrachochytrium dendrobatidis in Blanchard's Cricket Frog (Acris crepitans blanchardi) in the U.S. Midwest. Herpetological Review 39:193196.

Strate, R.H. 1987. A study of metachrosis in cricket frogs, Acris crepitans, from Johnson County, Missouri. MS Thesis. Central Missouri State University. Warrensburg, Missouri, U.S.A.

Swanson, D.L., S.L. Burdick. 2010. Overwintering physiology and hibernacula microclimates of Blanchard's Cricket Frogs at their northwestern range boundary. Copeia 2010:247-253.

Teodorovic, I., V. Knezevic, T. Tunic, M. Cucak, J.N. Lecic, A. Leovac, I.I. Tumbas. 2012. Myriophyllum aquaticum versus Lemna minor sensitivity and recovery potential after exposure to atrazine. Environmental Toxicology and Chemistry 31:417-426.

Vinebrooke, D., L. Rolf, K. Cottingham, M.S. Norberg, I.S. Dodson, C.S. Maberly, U. Sommer. 2004. Impacts of multiple stressors on biodiversity and ecosystem functioning: The role of species co-tolerance. Oikos 104:451-457.

Wisconsin Department of Natural Resources. 2015. 2015 - 2025 Wisconsin Wildlife Action Plan. Madison, Wisconsin, U.S.A.

Youngquist, M.B., M.D. Boone. 2014. Movement of amphibians through agricultural landscapes: The role of habitat on edge permeability. Biological Conservation 175:148-155.

Zippel, K., C. Tabaka. 2008. Amphibian Chytridiomycosis in captive Acris crepitans blanchardi (Blanchard's Cricket Frog) collected from Ohio, Missouri, and Michigan, U.S.A. Herpetological Review 39:192-193. 
Appendix 1. Locations charted for Blanchard's Cricket Frog (Acris blanchardi).

\begin{tabular}{|c|c|c|c|c|c|}
\hline \multirow[t]{2}{*}{ Location } & \multirow{2}{*}{$\begin{array}{l}\text { Abundance* } \\
\text { (or number) }\end{array}$} & \multirow{2}{*}{$\begin{array}{l}\text { Vegetation } \\
\text { type where } \\
\text { present** }\end{array}$} & \multirow{2}{*}{$\begin{array}{l}\text { Vegetation } \\
\text { type where } \\
\text { absent** }\end{array}$} & \multicolumn{2}{|c|}{$\begin{array}{c}\text { Est. Slope from } 30 \mathrm{~cm} \\
\text { above to } 30 \mathrm{~cm} \text { below } \\
\text { water edge }\end{array}$} \\
\hline & & & & Present & absent \\
\hline 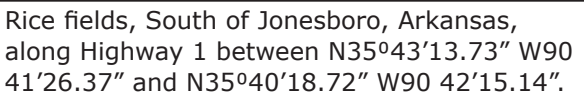 & ++++ & MFV, DW & CTG & $<30^{\circ}$ & $\begin{array}{l}>30^{\circ} \\
<30^{\circ}\end{array}$ \\
\hline $\begin{array}{l}\text { Gull Lake, Kellogg Biological Station (KBS), } \\
\text { Michigan. (June 1992) }\end{array}$ & NP & & SB, LG & & $\begin{array}{l}>30^{\circ} \\
<30^{\circ}\end{array}$ \\
\hline $\begin{array}{l}\text { Fishing Pier, Red River Research and Education } \\
\text { Park, Shreveport, LA (2003-2005). } \\
\text { N32 } 26^{\prime} 37.15^{\prime \prime} \text { W } 93^{\circ} 42^{\prime} 5.58^{\prime \prime}\end{array}$ & ++ & LG, DW, MFV & CTG & $<30$ & $\begin{array}{l}<30 \\
>30\end{array}$ \\
\hline $\begin{array}{l}\text { Point 2, Red River Research and Education } \\
\text { Park, Shreveport, LA ( } 2003-2005) \text {. } \\
\text { N32 } 26^{\prime} 41.96^{\prime \prime} \text { W93 } 93^{\circ} 41^{\prime} 51.28^{\prime \prime}\end{array}$ & NP & & CTG & & $\begin{array}{l}>30 \\
<30\end{array}$ \\
\hline $\begin{array}{l}\text { Point 4, Red River Research and Education } \\
\text { Park, Shreveport, LA (2003 - 2005). } \\
\text { N32 } 26^{\prime} 36.43^{\prime \prime} \text { W934 } 41^{\prime} 25.65^{\prime \prime}\end{array}$ & +++ & LG, MFV & CTG & $<30$ & $\begin{array}{l}>30 \\
<30\end{array}$ \\
\hline $\begin{array}{l}\text { Private lake, Highway 63, Arkansas (Monthly } \\
\text { from Oct. 1999 - Jan. 2003.) (N35052'37.24", } \\
\left.\text { W90 } 47^{\prime} 26.06^{\prime \prime}\right)\end{array}$ & ++++ & MFV, MF, DW & CTG & $<30^{\circ}$ & \\
\hline Quaking Bog, vic. Of KBS. (June 1992) & +++ & SFM, WL & CTG & $--* * *$ & -- \\
\hline $\begin{array}{l}\text { Betty Spring, vic. Lake Frierson, Jonesboro, } \\
\text { AR. (Summer 2001). } \\
\text { N35 } 58^{\prime} 20.59^{\prime \prime} \text { W90 } 44^{\prime} 06.70^{\prime \prime}\end{array}$ & +++++ & MFV, SV, LG & & $<30^{\circ}$ & \\
\hline Private pond, vic. Normal, IL. May 1992. & ++ & MFV, MF, DW & & $>30$ & \\
\hline $\begin{array}{l}\text { Sand Pond, Savanna Army Depot, Jo Daviess } \\
\text { County, IL (Summer 1994). } \\
\text { N42 } 13^{\prime} 55.72^{\prime \prime} \text { W90 } 19^{\prime} 13.16^{\prime \prime} \\
\text { (large bullfrog tadpole population) }\end{array}$ & NP & & $\begin{array}{l}\text { CTG, RS, SB, } \\
\text { MF, DW }\end{array}$ & & all \\
\hline $\begin{array}{l}\text { Creek, Savanna Army Depot, Jo Daviess } \\
\text { County, IL (Summer 1994). } \\
\text { N42 } 45^{\prime} 48.25 \text { W } 90^{\circ} 22^{\prime} 08.57^{\prime \prime} \\
\text { (Large populations L. pipiens, L. Palustrus). }\end{array}$ & NP & & TG, MF & & $>30^{\circ}$ \\
\hline 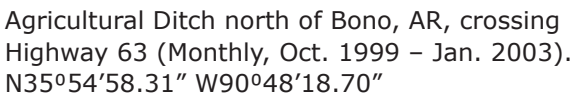 & +++ & MFV, DW, LG & MF, LG & $<30^{\circ}$ & $>30^{\circ}$ \\
\hline $\begin{array}{l}\text { Agricultural Ditch south of Jonesboro, } \\
\text { AR, along Highway 1, N35040'55.50" } \\
\text { W90 } 40^{\prime} 15.93^{\prime \prime}\end{array}$ & ++++ & DW, CTG & MFV, CTG & & $>30^{\circ}$ \\
\hline 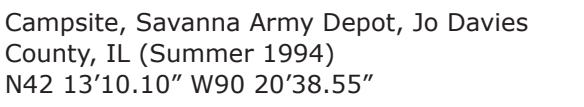 & NP & LG, CTG & & & all \\
\hline 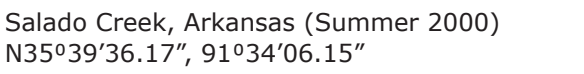 & 1 & MF & & & $>30^{\circ}$ \\
\hline $\begin{array}{l}\text { Dawt Mill Resort, Black River, Missouri. West } \\
\text { bank, north and south of bridge. (1999 - } \\
\text { 2003) N36 } 36^{\prime} 35.92^{\prime \prime} \text { W92 } 16^{\circ} 43.05^{\prime \prime}\end{array}$ & +++++ & GB, GBW, SV & & $\begin{array}{l}<30 \\
>30\end{array}$ & \\
\hline $\begin{array}{l}\text { Dawt Mill Resort, Black River, Missouri, } \\
\text { north and south of bridge }(1999-2003) \text {. } \\
\text { N36 } 36^{\prime} 32.98^{\prime \prime} \text { W92 } 16^{\circ} 42.79^{\prime \prime}\end{array}$ & + & RG, RGV & & & $>30$ \\
\hline $\begin{array}{l}\text { Giles Creek, Collinsville, IL (1979 - 2003), } \\
\text { N38 } 48^{\circ} 42.36^{\prime \prime} \text { W89 } 56^{\prime} 51.84^{\prime \prime}\end{array}$ & + & MFV, LG & CTG, MF & & \\
\hline $\begin{array}{l}\text { Rex Dr. Lake, Collinsville, IL (1979 - 1984) } \\
\text { N38 } 42^{\prime} 48.45^{\prime \prime} \text { W89 } 56^{\prime} 47.76^{\prime \prime}\end{array}$ & +++ & DW, CTG & CTG, MF & $>30$ & $>30$ \\
\hline $\begin{array}{l}\text { Lakeview Acres I, Collinsville, IL (1979 - } \\
\text { 1999), N38 } 42^{\prime} 41.24^{\prime \prime} \text { W89 56'58.34" }\end{array}$ & NP & & MF, RS, LG & & $>30$ \\
\hline $\begin{array}{l}\text { Lakeview Acres II, Collinsville, IL (1983 - } \\
1986), \text { N38 } 48^{\circ} 47.85^{\prime \prime} \text { W89 } 56^{\prime} 59.51^{\prime \prime}\end{array}$ & NP & & RS, LG & & $>30$ \\
\hline
\end{tabular}


Pasture Creek, Maryville IL (1983 - 1984) N38043'04.22" W89056'21.88"

Wooded Creek, Maryville, IL (1983 - 1984) N38043'03.81" W89056'27.69"

Wooded Creek, Maryville, IL (1983 - 1984) N38042'40.69" W89056'29.29"

Holden Lake, Holden, Missouri (2012

-2016) N38 45'52.07" W94 $02^{\prime} 22.03^{\prime \prime}$,

N38045'26.94" W94001'54.99", N38045'16.18"

W94 $02^{\prime} 05.63^{\prime \prime}$

Spillway, Lake Wright Patmann, Texarkana, Texas (2003 - 2011) N33018'21.02" W94009'24.65"

Waterfowl observation post, Lake Wright Patmann, Texarkana, Texas (2005 - 2011) N33019'42.49" W90009'41.81"

Jane's Creek (1999 - 2003) northeast of

Ravenden Springs, AR at

N36023'59.24" W91015'49.71"

Livestock pond at home (2012 - 2016)

N38 ${ }^{\circ} 47^{\prime} 13.06^{\prime \prime}$ W94002'02.89".

Home reservoir (2012 - 2016)

N38047'16.36" W94002'10.69"

Wooded Creek (2012 - 2016)

N38047'41.52" W94001'42.85"

Silver Lake Park, Highland, Illinois (1980 -

1987) N38046'01.49" W89041'38.99"

Wooded pond, Southern Illinois University

at Edwardsville campus (1995-1999)

N38047'32.36" W89059'16.64"

Langston University Campus ponds (2016 -

2017)

Pasture spring-pond along US 412 north

of Black Rock, AR. (1999-2002).

N3607'19.05" W91008'55.15"

Maryville Fishing Club Lake, Maryville, Illinois

(1983 - 2002)

N38043'41.33" W89056'58.70"

White Oak Park Lake, Normal, Illinois (1989

- 1992)

N40 29'38.43" W89 00'53.25"

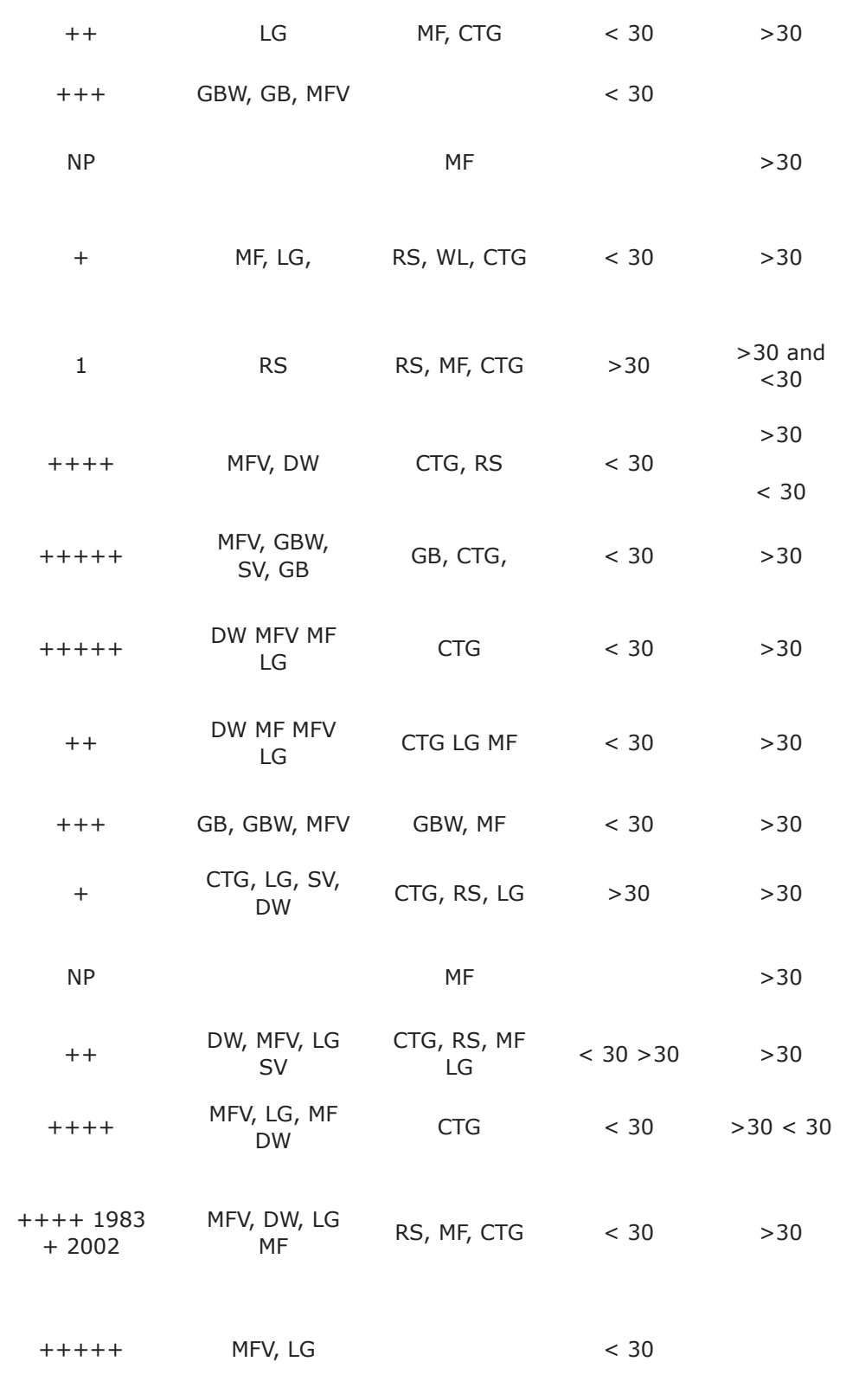

*Abundance: $\mathrm{NP}=$ not present,$+=$ rare,$++=$ not common,$+++=$ common,$+++=$ very abundant

** Key to vegetation types:

$\mathrm{GB}=$ gravel bed without vegetation

GBW = gravel bed with vegetation

$\mathrm{RG}=$ bedrock with some gravel

$\mathrm{RGV}=$ bedrock with some gravel and some taller vegetation.

$L G=$ lawn grass to edge of water

CTG $=$ thick bed of Cattails or tall grasses in water and along shoreline.

$\mathrm{RS}=$ rock shoreline, rubble for erosion control

$\mathrm{SB}=$ sand bottom, no shallow water vegetation, grass may be present on shoreline

$\mathrm{MF}=$ mud flat without aquatic vegetation, grasses or rushes were present within $30 \mathrm{~cm}$ of shore.

$\mathrm{MFV}=$ mud flat with aquatic or emergent vegetation including small rushes and grasses extending into the water.

SFM = sphaghnum floating mats

$\mathrm{DW}=$ floating duckweed, algal mats, or similar vegetation.

$\mathrm{SV}=$ thick, submerged vegetation creating mats at the surface including Ceratophyllum sp. and Myriophyllum sp.

$\mathrm{WL}=$ water lilies, water lotus and similar floating or emergent plants.

$\mathrm{TG}=$ tall grasses $(>2 \mathrm{~m}$ tall).

$* * *$ sphaghnum reaches far from shore into open water. Angle of sphaghnum not observed. 
Appendix 2. Multiple linear regression results for each of the five best models associating habitat observations with abundance of Blanchard's Cricket Frog (Acris blanchardi). (GBW = gravel banks without vegetation, SFM = Sphagnum mats, DW = duckweed-algal mats, SV = thick submerged floating mats of Ceratophyllum sp. or Myriophyllum sp. , slope $=$ shoreline slope $>30^{\circ}$ ).

\begin{tabular}{|c|c|c|c|c|c|c|}
\hline \multirow[t]{16}{*}{ Model 1} & \multicolumn{6}{|c|}{ Abundance $=1.82+1.43 \mathrm{GBW}+2.80 \mathrm{SFM}+1.23 \mathrm{DW}+1.50 \mathrm{SV}-1.62$ slope. } \\
\hline & \multicolumn{6}{|c|}{$R^{2}=0.573$. Durbin-Watson $=1.71$. No evidence of lack of fit $(P>0.1)$. } \\
\hline & Predictor & Coef & SE Coef & $\mathbf{T}$ & P & VIF \\
\hline & Constant & 1.8213 & 0.3590 & 5.07 & $<0.001$ & \\
\hline & GBW & 1.4262 & 0.6424 & 2.22 & 0.031 & 1.3 \\
\hline & SFM & 2.8020 & 1.2310 & 2.28 & 0.027 & 1.0 \\
\hline & DW & 1.2286 & 0.3997 & 3.07 & 0.003 & 1.3 \\
\hline & SV & 1.5044 & 0.5701 & 2.64 & 0.011 & 1.2 \\
\hline & Slope & -1.6232 & 0.3711 & -4.37 & $<-0.001$ & 1.2 \\
\hline & \multicolumn{6}{|c|}{ Analysis of Variance } \\
\hline & Source & Df & SS & MS & $\mathbf{F}$ & $\mathbf{P}$ \\
\hline & Regression & 5 & 104.550 & 20.910 & 14.23 & $<0.001$ \\
\hline & Residual error & 53 & 77.857 & 1.469 & & \\
\hline & Lack of fit & 5 & 24.901 & 4.980 & 4.51 & 0.002 \\
\hline & Pure error & 48 & 52.956 & 1.103 & & \\
\hline & Total & 58 & 182.407 & & & \\
\hline \multirow[t]{15}{*}{ Model 2} & \multicolumn{6}{|c|}{ Abundance $=1.82+143 \mathrm{~GB}+2.80 \mathrm{SFM}+1.23 \mathrm{DW}+1.50 \mathrm{SV}-1.62$ slope } \\
\hline & \multicolumn{6}{|c|}{$R^{2}=0.573$. Durbin-Watson $=1.93$. No evidence of lack of fit $(P>0.1)$} \\
\hline & Predictor & Coef & SE Coef & $\mathbf{T}$ & $\mathbf{P}$ & VIF \\
\hline & Constatant & 1.8213 & 0.3590 & 5.07 & $<0.001$ & \\
\hline & $\mathrm{GB}$ & 1.4262 & 0.6424 & 2.22 & 0.031 & 1.3 \\
\hline & SFM & 2.8020 & 1.2310 & 2.28 & 0.027 & 1.0 \\
\hline & DW & 1.2286 & 0.3997 & 3.07 & 0.003 & 1.3 \\
\hline & SV & 1.5044 & 0.5701 & 2.64 & 0.011 & 1.2 \\
\hline & \multicolumn{6}{|c|}{ Analysis of Variance } \\
\hline & Source & Df & SS & MS & $\mathbf{F}$ & $\mathbf{P}$ \\
\hline & Regression & 5 & 104.550 & 20.910 & 14.23 & $<0.001$ \\
\hline & Residual error & 53 & 77.857 & 1.469 & & \\
\hline & Lack of fit & 5 & 24.901 & 4.980 & 4.51 & 0.002 \\
\hline & Pure error & 48 & 52.956 & 1.103 & & \\
\hline & Total & 58 & 182.407 & & & \\
\hline \multirow[t]{16}{*}{ Model 3} & \multicolumn{6}{|c|}{$\begin{array}{l}\text { Abundance }=1.24+1.32 \mathrm{GBW}+0.912 \mathrm{MFV}+2.81 \\
\mathrm{R}^{2}=0.593 . \text { Durbin-Watson }=2.02 \\
\text { Possible curvature in variable DW }(\mathrm{P}=0.011) \\
\text { Possible interactions with variable } \mathrm{DW}(\mathrm{P}=0.012) \\
\text { Possible interactions with variable SV }(\mathrm{P}=0.026) \\
\text { Possible curvature in variable "slope" }(\mathrm{P}=0.061) \\
\text { Possible lack of fit at outer } \mathrm{x} \text {-values }(\mathrm{P}=0.029) \\
\text { Overall lack of fit test is significant }(\mathrm{P}=0.011)\end{array}$} \\
\hline & Predictor & Coef & SE Coef & $\mathbf{T}$ & $\mathbf{P}$ & VIF \\
\hline & Constant & 1.2413 & 0.5077 & 2.45 & 0.018 & \\
\hline & GB & 1.3169 & 0.6370 & 2.07 & 0.044 & 1.3 \\
\hline & MFV & 0.9117 & 0.5721 & 1.59 & 0.117 & 3.1 \\
\hline & SFM & 2.8120 & 1.2140 & 2.32 & 0.024 & 1.0 \\
\hline & DW & 0.9145 & 0.4406 & 2.08 & 0.043 & 1.6 \\
\hline & SV & 1.2900 & 0.5779 & 2.23 & 0.030 & 1.3 \\
\hline & slope & -1.0529 & 0.5117 & -2.06 & 0.045 & 2.4 \\
\hline & \multicolumn{6}{|c|}{ Analysis of Variance } \\
\hline & Source & Df & SS & MS & $\mathbf{F}$ & $\mathbf{P}$ \\
\hline & Regression & 6 & 108.1750 & 18.029 & 12.63 & $<0.001$ \\
\hline & Residual error & 52 & 74.2320 & 1.428 & & \\
\hline & Lack of fit & 8 & 33.2860 & 4.161 & 4.47 & 0.001 \\
\hline & Pure error & 44 & 40.9450 & 0.931 & & \\
\hline & Total & 58 & 182.4070 & & & \\
\hline
\end{tabular}


Model 4

Abundance $=1.24+1.32 \mathrm{~GB}+0.912 \mathrm{MFV}+2.81 \mathrm{SFM}+0.915 \mathrm{DW}+1.29 \mathrm{SV}-1.05$ slope

$\mathrm{R}^{2}=0.593$. Durbin-Watson $=2.02$

Possible interactions with variable DW $(P=0.001)$

Possible lack of fit at outer $x$-values $(P=0.022)$

Overall lack of fit test is significant $(P=0.001)$

\begin{tabular}{|c|c|c|c|c|c|}
\hline Predictor & Coef & SE Coef & $T$ & $\mathbf{P}$ & VIF \\
\hline Constant & 1.2413 & 0.5077 & 2.45 & 0.018 & \\
\hline GB & 1.3169 & 0.6370 & 2.07 & 0.044 & 1.3 \\
\hline MFV & 0.9117 & 0.5721 & 1.59 & 0.117 & 3.1 \\
\hline SFM & 2.8120 & 1.2140 & 2.32 & 0.024 & 1.0 \\
\hline DW & 0.9145 & 0.4406 & 2.08 & 0.043 & 1.6 \\
\hline SV & 1.2900 & 0.5779 & 2.23 & 0.030 & 1.3 \\
\hline slope & -1.0529 & 0.5117 & -2.06 & 0.045 & 2.4 \\
\hline \multicolumn{6}{|c|}{ Analysis of Variance } \\
\hline Source & Df & SS & MS & $\mathbf{F}$ & $\mathbf{P}$ \\
\hline Regression & 6 & 108.1750 & 18.029 & 12.63 & $<0.001$ \\
\hline Residual error & 52 & 74.2320 & 1.428 & & \\
\hline Lack of fit & 8 & 33.2860 & 4.161 & 4.47 & 0.001 \\
\hline Pure error & 44 & 40.9450 & 0.931 & & \\
\hline Total & 58 & 182.4070 & & & \\
\hline
\end{tabular}

Model $5 \quad$ Abundance $=1.41+1.31 \mathrm{GBW}-0.396 \mathrm{MF}+0.844 \mathrm{MFV}+2.63 \mathrm{SFM}+0.999 \mathrm{DW}+1.19 \mathrm{DW}-1.04$ slope $\mathrm{R}^{2}=0.604$. Durbin-Watson $=1.88$

Possible lack of fit at outer $x$-values $(P=0.056)$

Overall lack of fit test is significant at $\mathrm{P}=0.056$.

\begin{tabular}{|c|c|c|c|c|c|}
\hline Predictor & Coef & SE Coef & $T$ & $\mathbf{P}$ & VIF \\
\hline Constant & 1.4071 & 0.5238 & 2.69 & 0.010 & \\
\hline GBW & 1.3065 & 0.6342 & 2.06 & 0.045 & 1.3 \\
\hline MF & -0.3962 & 0.3285 & -1.21 & 0.233 & 1.1 \\
\hline MFV & 0.8438 & 0.5724 & 1.47 & 0.147 & 3.1 \\
\hline SFM & 2.6310 & 1.2180 & 2.16 & 0.035 & 1.0 \\
\hline DW & 0.9993 & 0.4443 & 2.25 & 0.029 & 1.7 \\
\hline SV & 1.1869 & 0.5817 & 2.04 & 0.046 & 1.3 \\
\hline Slope & -1.0386 & 0.5097 & -2.04 & 0.047 & 2.4 \\
\hline \multicolumn{6}{|c|}{ Analysis of Variance } \\
\hline Source & Df & SS & MS & $\mathbf{F}$ & $\mathbf{P}$ \\
\hline Regression & 7 & 110.234 & 15.748 & 11.13 & $<0.001$ \\
\hline Residual error & 51 & 72.173 & 1.415 & & \\
\hline Lack of fit & 12 & 40.916 & 3.410 & 4.25 & $<0.001$ \\
\hline Pure error & 39 & 31.256 & 0.801 & & \\
\hline Total & 58 & 182.407 & & & \\
\hline
\end{tabular}

**Key to vegetation types:

$\mathrm{GB}=$ gravel bed without vegetation

GBW = gravel bed with vegetation

$\mathrm{RG}=$ bedrock with some gravel

$\mathrm{RGV}=$ bedrock with some gravel and some taller vegetation.

$\mathrm{LG}=$ lawn grass to edge of water

CTG $=$ thick bed of Cattails or tall grasses in water and along shoreline.

$\mathrm{RS}=$ rock shoreline, rubble for erosion control

$\mathrm{SB}=$ sand bottom, no shallow water vegetation, grass may be present on shoreline

$\mathrm{MF}=$ mud flat without aquatic vegetation, grasses or rushes were present within $30 \mathrm{~cm}$ of shore.

MFV = mud flat with aquatic or emergent vegetation including small rushes and grasses extending into the water.

SFM = sphagnum floating mats

DW = floating duckweed, algal mats, or similar vegetation

$\mathrm{SV}=$ thick, submerged vegetation creating mats at the surface including Ceratophyllum sp. and Myriophyllum sp.

$\mathrm{WL}=$ water lilies, water lotus and similar floating or emergent plants.

$\mathrm{TG}=$ tall grasses $(>2 \mathrm{~m}$ tall) .

***sphagnum reaches far from shore into open water. Angle of sphagnum not observed. 
Appendix 3. Multiple linear regression results for each of the five best models associating consolidated habitat observations with abundance of Blanchard's Cricket Frog (Acris blanchardi). ( $\mathrm{G}=$ gravel banks; SF $=$ floating vegetation, slope $=$ shoreline slope $>$ $30^{\circ}$ or $\left.<30^{\circ}\right)$.

Model 1

Abundance $=1.41+1.21 \mathrm{G}+2.01 \mathrm{FM}-1.25$ (slope $>30)$.

$\mathrm{R}^{2}=0.603$. Durbin-Watson $=1.71$.

Possible lack of fit $(P=0.007)$.

Overall lack of fit test significant $(P=0.007)$

Coef SE Coef

FM

$\begin{array}{ll}1.4141 & 0.3376 \\ 1.2097 & 0.4986\end{array}$

0.4986

$0.3419 \quad-3.66$

$\mathrm{T}$
4.19

4.19
2.43

$>30^{\circ}$ slope $\quad-1.2524$

Analysis of Variance

Source

Regression

Residual error

SS MS

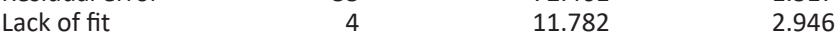

Pure error

11.782
60.679

182.407

Model 2

Abundance $=1.39+1.18 \mathrm{G}+1.25 \mathrm{FM}-1.62$ slope $>30^{\circ}$

$\mathrm{R}^{2}=0.619$. Durbin-Watson $=1.78$.

Possible curvature in variable sub veg $(P=0.003)$

Possible interactions with slope $>30(P=0.019)$.

Overall lack of fit test is significant at $P>0.003$.

$\begin{array}{lccrrr}\text { Predictor } & \text { Coef } & \text { SE Coef } & \text { T } & \text { P } & \text { VIF } \\ \text { Constant } & 1.3851 & 0.3344 & 4.14 & <0.001 & \\ \text { G } & 1.1788 & 0.4935 & 2.39 & 0.020 & 1.0 \\ \text { SB } & -1.2468 & 0.8301 & -1.50 & 0.139 & 1.0 \\ \text { FM } & 2.0635 & 0.3342 & 6.17 & <0.001 & 1.2 \\ \text { Slope }>30^{\circ} & -1.1701 & 0.3425 & -3.42 & 0.001 & 1.2\end{array}$

Analysis of Variance

Source

Df SS MS

Regression

112.852

28.213

Residual error

69.555

$16.031 \quad 3.206$

Lack of fit

$\begin{array}{lrr}\text { Pure error } & 49 & 53.524 \\ \text { Total } & 58 & 182.407\end{array}$

Model 3

Abundance $=1.50+1.12 \mathrm{G}-0.514 \mathrm{CTG}+1.93 \mathrm{FM}-1.02\left(\right.$ slope $\left.>30^{\circ}\right)$

$\mathrm{R}^{2}=0.617$. Durbin-Watson $=1.66$

No evidence of lack of fit $(P>0.1)$

\begin{tabular}{|c|c|c|c|c|c|}
\hline Predictor & Coef & SE Coef & $\mathbf{T}$ & P & VIF \\
\hline Constant & 1.4993 & 0.3396 & 4.42 & $<0.001$ & \\
\hline G & 1.1212 & 0.4977 & 2.25 & 0.028 & 1.0 \\
\hline CTG & -0.5136 & 0.3570 & -1.44 & 0.156 & 1.4 \\
\hline FM & 1.9303 & 0.3370 & 5.73 & $<0.001$ & 1.2 \\
\hline Slope $>30^{\circ}$ & -1.0233 & 0.3742 & -2.73 & 0.008 & 1.4 \\
\hline \multicolumn{6}{|c|}{ Analysis of Variance } \\
\hline Source & Df & SS & MS & $\mathbf{F}$ & $\mathbf{P}$ \\
\hline Regression & 4 & 112.622 & 28.155 & 21.79 & $<0.001$ \\
\hline Residual error & 54 & 69.785 & 1.292 & & \\
\hline Lack of fit & 7 & 12.803 & 1.829 & 1.51 & 0.188 \\
\hline Pure error & 47 & 56.982 & 1.212 & & \\
\hline Total & 58 & 182.407 & & & \\
\hline \multicolumn{6}{|c|}{$\begin{array}{l}\text { Abundance }=1.47+1.09 \mathrm{G}-0.523 \mathrm{CTG}-1.27 \mathrm{SB}+1.99 \mathrm{FM}-0.936 \text { slope }>30^{\circ} \\
\mathrm{R}^{2}=0.593 . \text { Durbin-Watson }=1.74 \\
\text { Possible curvature in variable FM }(P=0.009) \\
\text { Overall lack of fit test is significant }(P=0.009)\end{array}$} \\
\hline Predictor & Coef & SE Coef & $\mathbf{T}$ & $\mathbf{P}$ & VIF \\
\hline Constant & 1.4714 & 0.3358 & 4.38 & $<0.001$ & \\
\hline G & 1.0882 & 0.4919 & 2.21 & 0.031 & 1.0 \\
\hline CTG & -0.5228 & 0.3525 & -1.48 & 0.144 & 1.4 \\
\hline SB & -1.2674 & 0.8211 & -1.54 & 0.129 & 1.0 \\
\hline FM & 1.9858 & 0.3347 & 5.93 & $<0.001$ & 1.2 \\
\hline Slope $<30^{\circ}$ & -0.9355 & 0.3739 & -2.50 & 0.015 & 1.5 \\
\hline \multicolumn{6}{|c|}{ Analysis of Variance } \\
\hline Source & Df & SS & MS & $\mathbf{F}$ & P \\
\hline Regression & 5 & 115.624 & 23.125 & 18.35 & $<0.001$ \\
\hline Residual error & 53 & 66.783 & 1.260 & & \\
\hline Lack of fit & 8 & 15.216 & 1.902 & 1.66 & 0.135 \\
\hline Pure error & 45 & 51.567 & 1.146 & & \\
\hline Total & 58 & 182.407 & & & \\
\hline
\end{tabular}


Abundance $=0.548+1.09 \mathrm{G}-0.864 \mathrm{CTG}-1.88 \mathrm{SB}+2.04 \mathrm{FM}+0.743-0.743$ slope $<30^{\circ}$

$\mathrm{R}^{2}=0.630$. Durbin-Watson $=1.82$

Possible curvature in variable FM $(P=0.002)$

Overall lack of fit test is significant at $P=0.002$.

\begin{tabular}{|c|c|c|c|c|c|}
\hline Predictor & Coef & SE Coef & $\mathbf{T}$ & $\mathbf{P}$ & VIF \\
\hline Constant & 0.5479 & 0.2994 & 1.83 & 0.073 & \\
\hline G & 1.0886 & 0.4947 & 2.20 & 0.032 & 1.0 \\
\hline CTG & -0.8642 & 0.3215 & -2.69 & 0.010 & 1.1 \\
\hline SB & -1.8772 & 0.8256 & -2.27 & 0.027 & 1.0 \\
\hline FM & 2.0361 & 0.3323 & 6.13 & $<0.001$ & 1.2 \\
\hline Slope $<30^{\circ}$ & 0.7434 & 0.3137 & 2.37 & 0.021 & 1.1 \\
\hline \multicolumn{6}{|c|}{ Analysis of Variance } \\
\hline Source & Df & SS & MS & $\mathbf{F}$ & $\mathbf{P}$ \\
\hline Regression & 5 & 114.889 & 22.978 & 18.04 & $<0.001$ \\
\hline Residual error & 53 & 67.517 & 1.274 & & \\
\hline Lack of fit & 7 & 15.619 & 2.231 & 1.98 & 0.079 \\
\hline Pure error & 46 & 51.899 & 1.128 & & \\
\hline Total & 58 & 182.407 & & & \\
\hline
\end{tabular}

